\title{
sciendo
}

\section{Salespeople's innovativeness: a driver of sales performance}

\author{
Augusty Tae FERDINAND \\ Faculty of Economics and Business Diponegoro University, Semarang, Indonesia \\ augusty@live.undip.ac.id \\ Wahyuningsih WAHYUNINGSIH \\ Faculty of Economics and Business Tadulako University, Palu, Indonesia \\ wahyuningsih.wahyuningsih@untad.ac.id
}

\begin{abstract}
The purpose of this study is to develop a conceptual model for explaining the process of how salespeople's innovativeness leverages sales performance by introducing the organizational learning-based factors such as sales team tacit knowledge exchange, valuebased selling capability, and a positive selling ambiance initiative in the selling process to enhance sales performance. The novelty of this study is its construction of a conceptual model that adopts the organizational learning framework both in cultivating the organizational memory of salespeople working in a sales organization and in processing organizational memory for leveraging capabilities that lead to better sales performance. The acceptance of the proposed hypotheses demonstrated the importance of organizational learning-based factors in supporting the success of salespeople in the consumer product market.
\end{abstract}

Keywords: salespeople innovativeness, knowledge exchange, value-based selling capability, selling ambiance, sales performance.

Please cite the article as follows: Ferdinand, A.T. and Wahyuningsih, W. (2018), "Salespeople's innovativeness: a driver of sales performance", Management \& Marketing. Challenges for the Knowledge Society, Vol. 13, No. 2, pp. 966-984, DOI: 10.2478/mmcks-2018-0016.

\section{Introduction}

Studies on entrepreneurial marketing and innovative selling are of increasing interest to both academics and practitioners (Hallbäck and Gabrielsson, 2013, Ionitã, 2012, Fiore et al., 2017, Glińska-Neweś et al., 2017, Ali, 2018, Choi et al., 2015), which indicates that entrepreneurial marketing plays a key role in developing better performance in the sense that marketing not only should be managed innovatively and proactively but also should always be open to new methods (Hallbäck and Gabrielsson, 2013, Ionitã, 2012, Smith and Lohrke, 2008, Morris et al., 2002). A salesperson who is energized by an entrepreneurial marketing spirit is one of the key persons in the marketing line and therefore should act creatively in the very competitive market. Employee's innovativeness is recognized as a determinant for success (Ali, 2018, Glińska-Neweś et al., 2017, Chen et al., 2015), particularly salespeople's innovativeness is believed to be a key driver of marketing performance (Chen et al., 2015). However, Lacroix et al. (2014) arrived at a different result indicating that not all types of salesperson innovativeness can enhance performance. They found that both innovative idea promotion and innovative idea realizations are not significant in enhancing sales performance. Yet, it remains unclear what type of process could be developed by innovative salespeople to positively impact on enhancing sales performance 
This study aims to fill up this research gap through building a conceptual model based on organizational learning platform in processing the salespeople innovativeness for leveraging sales performance. Adopting the organizational learning theory, a conceptual model is developed to explain the process of how salespeople's innovativeness is empowered and how innovativeness energizes the process for enhancing sales performance. Organization learning theory is applied in this study for its capability in creating and enhancing organizational learning stocks (Bontis et al., 2002) as a portfolio of professional competence through several method such as team building, knowledge sharing, especially tacit knowledge exchange practices at the organizational level. A study of Stuart (2016) pinpointed the pivotal role of organizational learning in building core competencies leads through sales team tacit knowledge exchange (Eng, 2006), value-based selling capability, and positive selling ambiance initiative (Chakrabarty et al., 2014) in the selling process to enhance sales performance. The model is then tested in the context of selling coffee-based snack and beverage products in Indonesia.

\section{Literature review and hypothesis development}

Tacit knowledge exchange in the organizational learning theory framework

Organizational learning as an organizational culture can be embedded in the history line of an organization or company if done either regularly or incidentally. One of the basic frameworks of organizational learning involves adopting a learning process as an organizational task to facilitate the process of knowledge acquisition, knowledge distribution, knowledge interpretation and building an organizational memory (Jiménez-Jiménez and Sanz-Valle, 2011) to empower the organization's intellectual capital for better performance. Organizational learning is conducted to create or enhance either individual-level learning stocks or organizational-level learning stocks (Bontis et al., 2002) as a portfolio of knowledge, skill and attitudes for handling jobs in the organization. Organizational learning can be seen through an organizational routine such as competency development through team building, for example, by asking other team members what they did and could do differently to enhance performance and when problems arise, investigating them to learn how to prevent them in the future (Heap, 1996), thus empowering teams with explicit knowledge and tacit knowledge for having a strong knowledge-based team.

For decades, organizational leaning has been recognized as a knowledge-based strategic instrument for empowering teamwork in enhancing performance. Studies have demonstrated the influence of organizational learning to enhance business performance (López Sánchez et al., 2011), innovativeness (Škerlavaj et al., 2010), organizational innovation and performance (García-Morales et al., 2012). Yu et al. (2013) demonstrated that the utilization of knowledge management systems and organizational learning is an important anchor for translating business insight into a real innovation capability. One condition for expecting a positive effect of organizational learning is the existence of a management system that is ruled under a transformational leadership environment and that influences organizational performance positively through organizational learning and innovation (GarcíaMorales et al., 2012). When learning is conducted through teamwork in a learning network between groups, group members are seen as a social learning network with 
the potential to enhance business processes such as reducing learning time and improving productivity (Bologa and Lupu, 2014). Moreover, organizational learning in a form such as a knowledge-exchange process significantly contributes to supporting incremental innovation in the organization (Sheng and Chien, 2016). Previous studies have also demonstrated the ability of organizational learning practices, supported by a firm's quality management capability of acting as a strategic instrument, to provide customer value (Malik et al., 2012) and improve performance (Hu, 2014, SantosVijande et al., 2012). Organizational learning as a part of knowledge management done through among others knowledge exchange, tacit knowledge exchange could be seen as a spirit to achieve superior company performance(Subanidja and Hadiwidjojo, 2017).Therefore study on the process and the impact of organization learning through the mode of tacit knowledge exchange and its consequences could be seen as an effort to detail the organizational learning and knowledge management that potential to give spread effects on management functions (Subanidja and Hadiwidjojo, 2017). Organizational learning and a tacit knowledge sharing mechanism is recognized as a process for creating an effective team works as concluded in the study of Rahman et al. (2015) as media for "create a work-environment where the sense of community among the teams, feeling of respecting others values, feelings of respecting the institutional values, tended to assist others colleagues and experience of enjoyment of the workplace may exist", that directly weaponing the sales force for striving better in the market place.

\section{Salespeople's tacit knowledge exchange and salespeople innovativeness}

As scholars have previously noted, knowledge is a type of transient resource whose relevance and credibility are both time and context dependent (Mie and Morten Thanning, 1999) and may be classified into explicit knowledge and tacit knowledge. Tacit knowledge is a type of knowledge that cannot be articulated or verbalized; it resides in an intuitive realm (Foos et al., 2006) but can be utilized effectively in work life. The study of Matošková and Směšná (2017) concluded that one of the basic dimensions of knowledge sharing in the organization are knowledge interactions. A knowledge interaction content is sharing or exchanging several tacit knowledge coming from a life-time experience of teamwork member that is easy to be explained but hard to be codified as explicit knowledge. Knowledge interaction has a capability for blending various tacit information to create a way for making ways in achieving superior company performance (Subanidja and Hadiwidjojo, 2017). Extending the study of Arnett and Wittmann (2014), which found that one unexplored issue in tacit knowledge exchange is how salespeople develop a social network within the sales peer group in the sense that tacit knowledge exchange can be used to weaponize a salesperson with the ability to gather and articulate values in his or her sales conversations. Studies on tacit knowledge in sales management have attracted scholars to explore the root of tacit knowledge building, tacit knowledge processing and tacit knowledge exploitation with the goal of improving an organization's work quality and performance. Tacit knowledge can be understood as an unwritten experience, unarticulated knowledge or uncodified knowledge that can be learned through collaborative experience (Cavusgil et al., 2003).

Efforts to articulate and professionally exploit tacit knowledge will leverage the ability to increase the value of products and the value of a salesperson's selling Vol. 13, No. 2, Summer, pp. 966-984, ISSN 1842-0206 | Management \& Marketing. Challenges for the Knowledge Society 
activities. In turn, tacit knowledge exchange could be the medium for enriching a salesperson's peer's capabilities for success, as demonstrated by Cavusgil et al. (2003), who found that the greater the tacit knowledge transfer, the more likely the firm is to innovate effectively. Because tacit knowledge is difficult to articulate, in an effort to transfer or exchange tacit knowledge, the receiver could create implemented knowledge (Bennet and Bennet, 2008).

Tacit knowledge resides in a salesperson's mind, being acquired from a long portfolio of experience in the marketplace, such as experience in handling intense competition between salesforces from a variety of companies, failure to close a sale with a customer, spiritual factors relating to a customer, primordial nuance in selling to certain customers (for example, customers who prefer a salesperson of an ethical background) etc. A process of externalization such as exchanging between peers, training or voluntary sharing between peers in the selling process is expected to enhance performance (Sigala and Chalkiti, 2007); tacit knowledge ultimately helps organizations (especially salesforces) to achieve long-term organizational success and economic gains (Chen and Mohamed, 2010). One result of tacit knowledge exchanging processes is the accumulation of articulated knowledge, skill, and attitude that should be considered as a valuable asset (Holste and Dail, 2010, Zaim et al., 2015). If this asset is routinely or voluntarily shared among peer workers, professional performance can be established on the part of the individuals with whom the asset is shared. A good exchange of tacit knowledge has huge potential to empower salesforce creativity (Alwis and Hartmann, 2008), mirrored in innovative actions in the sales process. A previous study provides a lesson learned that salespeople with greater learning orientation as mirrored in tacit knowledge exchange practices tend to strengthen their selling skills and knowledge by seeking information on customers and other relevant market data (Yen-Chun et al., 2017) as a media for enhancing their innovativeness in encountering the customers. Based on the aforementioned discussion, it is proposed that:

H1: Sales team tacit knowledge exchange positively influences salespeople's innovativeness.

\section{Sales team tacit knowledge exchange, positive selling ambience initiative, and performance}

One important psychological aspect of selling is the concept of positive selling ambience, which explains why success depends on the ability to initiate or create positive encounters with consumers in the marketplace. Adopting the approach of Chakrabarty et al. (2014), this study defines a positive selling ambiance initiative as a salesperson's ability to initiate an energized sales-talk process by initiating an influential atmosphere in sales conversation, initiating positive-twist conversation, and creating comfortable feelings in sales conversations, thus facilitating customers' positive acceptance. Initiating a positive selling ambience may come from a salesperson that as a good service related ambience attribute such as friendly and helpful, attentive (Shahzadi et al., 2018) when encountering with the customers. Tacit knowledge exchange is expected to be a medium for transferring unarticulated knowledge and experience to be internalized individually to salespeople, 
transplanting uncodified experience and skills to be experienced by others for leveraging individual capabilities in their jobs, especially in the sales-encountering process. Accordingly, the following hypothesis is proposed:

H2: Sales team tacit knowledge exchange positively influences a positive selling ambience initiative.

Studies of selling ambience can be referenced for their concept of interactions between customers and salespeople (Kim and Kim 2012) that create a selling ambience with core working habits focused on listening to customers, creating positive nuance in sales conversation, having adequate knowledge, fulfilling customer needs and addressing consumers' emotions in interaction situations, all of which are significant prerequisites for a high-impact sales conversation. Salespeople with high capabilities to initiate positive selling ambiance are expected to win customers' hearts, thereby demonstrating good sales performance. As demonstrated by (Chakrabarty et al., 2014), salespeople's interpersonal mentalizing ability in creating a positive ambience impacts sales performance. Salespeople with the ability to initiate positive ambience in selling will have the potential to enhance sales performance such as sales volume in terms of the number of units sold (Mariadoss et al., 2014, Guenzi et al., 2014, Flaherty and Pappas, 2012), sales value in terms of monetary value created by the number of units sold (Mariadoss et al., 2014, Flaherty and Pappas, 2012), and sales growth (Chakrabarty et al., 2014, Spillecke and Brettel, 2013). Therefore, the following hypothesis is proposed:

H3: Positive selling ambience initiative positively influences sales performance.

\section{Salespeople's innovativeness and value-based selling capability}

Derived from the concept of entrepreneurial marketing, a salesperson should behave entrepreneurially to innovatively manage his/her customers, to facilitate new opportunity seeking, create entrepreneurial value, to attempt to escape from his/her comfort zone during selling, and to be innovative in the selling process. Extending the study of Chen and Mohamed (2010), salespeople's innovativeness is defined as a salesperson's entrepreneurial characteristics as personal traits and creativity in executing the sales job. Salespeople's innovativeness can be understood as a set of entrepreneurial characteristics embedded in a salesperson from two perspectives: first, as set of input characteristics known as creative personal traits, which are developed throughout one's professional life in a sales organization and are historically embedded in a person; second, as a set of process characteristics in a form of creativity in executing the sales job. From the perspective of personal traits, an innovative salesperson is a creative salesperson who demonstrates open-minded behaviour and who is open minded in reacting or responding to customer complaints (Tjosvold et al., 1999). Several studies have demonstrated that a gain can be expected from an open-minded person experiencing success in creating good performance. In the selling process or interaction with customers, open-mindedness (Paparoidamis, 2005) is necessary for leveraging performance. In contrast, a salesforce that is low in openness, for example, by being closed minded, myopic, or using non-creative methods, tends to have lower performance (Burke and Witt, 2002).

Vol. 13, No. 2, Summer, pp. 966-984, ISSN 1842-0206 | Management \& Marketing. Challenges for the Knowledge Society 
An innovative salesperson is a creative person with high creative self-efficacy, and high creative expectations will lead to higher individual sales performance (Lacroix et al., 2014). An innovative salesperson can be identified as an individual with creative methods of selling, out-of-the-box thinking (Cangemi and Miller, 2007) and an eagerness to explore new methods. A salesperson with this characteristic will behave innovatively and positively, which leads to functioning creatively when selling a product. A person who is an out-of-the-box doer has the potential to develop new and unexpected sales methods and because of his creativity, he has the potential to develop several different methods for solving the same problem. Extending the findings of Cangemi and Miller (2007), creative or innovative teamwork and a creative or innovative workplace encourages a salesperson to engage in "out-of-the-box" thinking and contributes to better performance.

Understanding an innovative salesperson from the perspective of creativity in executing a job is the next critical aspect. An innovative salesforce is creative in exploring the selling process, is proactive in seeking new methods when selling, creative in articulating the value proposition when selling, has a unique approach in creating new challenge zones when leaving the comfort zone of selling (Kuo-Pin et al., 2015), is creative in problem solving, and is innovative in handling complaints and resistance. This type of salesperson has the ability to provide value, articulate value, provide solutions, overcome obstacles in a positive fashion, create positive ambience in selling and positive customer engagement, and therefore can trigger better sales performance, including selling a new product (Chen et al., 2015). An innovative salesperson is seen from at least three different aspects-idea generation, idea promotion and idea realization (Lacroix et al., 2014) - although idea promotion does not influence sales performance. The insignificant influence of innovativeness on sales performance drives this study to propose that innovativeness as an input process should be realized in an action type of strategic bridge for leveraging the value-based selling capability. Therefore, an innovative salesperson should enhance sales performance by innovatively delivering the best service value.

\section{Value-based selling capability}

The concept of value-based selling capability is adapted from the studies of Töytäri et al. (2011) and Töytäri and Rajala (2015) on the ability of value planning, value implementation and value leveraging to bond the customer, along with the study of Ruiz et al. (2008) on the role of service value in enhancing customer satisfaction and repurchase intention. This study considers the role of an innovative salesperson in bonding to the distribution channel customer who intermediates the flow of product from the manufacturer to the end user. An innovative salesperson, based on his/her innovative traits and process, will create and emphasize the value proposition for his/her offerings to the customer for a given price. He should be able to articulate and communicate the value proposition that represents the value of his offerings, such as the value of the customer's time, effort and money (Lee et al., 2010). Moreover, salespeople should not only make customers feel that they received their money's worth for the product and all the services embedded in delivering the product, but also verify that they have delivered the best value to customers. 
One of the key differentiators of a successful salesperson is his/her ability to leverage sales value to his/her customer in the sales process. Adapting Ruiz et al. (2008), we argue that a successful salesperson works with the ability to offer good service for the price he/she offers to customers. In the face of today's hypercompetitive business environment in terms of the density of suppliers for the same distribution customer and intense competition in terms of the substantial opportunity for substitute products, a salesperson must articulate the value of his/her offerings, particularly their worth in time, effort and money. A successful salesperson should have the ability to make customers feel that they are getting their money's worth. An innovative salesperson with a creative selling ability is creative in finding new methods of selling and solving problems will leverage sales value for the salesperson's customers. Therefore, it is proposed that:

H4: Salespeople innovativeness positively influences value-based selling capability.

\section{Value-based selling capability and sales performance}

An innovative salesperson has a portfolio of value-articulating, value-delivering capabilities such as the ability to convince the customer that the company offers a good-value produce for the price, a product that is valuable in terms of time, effort and money, and the ability to influence customers to understand the product's monetary worth, Ruiz et al. (2008). Because a salesperson develops a basis for cooperating with a customer in selling products to end-users, value creation and value delivery are prerequisites for interactions and commitment (Trond and Kjell, 2010) as a basis for enhancing and sustaining sales performance. As supported by Kim et al. (2010), th effort to provide value is a key to enhancing sales performance, for example, by acquiring a good market share, generating a high level of monetary sales, generating sales to new customers, and exceeding sales targets (Lilford et al., 2014). Therefore, the following hypothesis is proposed:

H5: Value-based selling capability positively influences sales performance.

\section{Research method}

\section{Sample and data collection}

The respondents are sampled from 49 sub-branch offices/ stock point depots of consumer products in Indonesia. The sub-branch office is managed by a sales supervisor who agreed to participate in this research. The sub-branch offices are the operational units of a marketing company owned by a food and beverage manufacturer, producing several product classes for more than 500 items that are sold across Indonesia and several countries in South East Asia. The study's area is formed of all the provinces in the Java Island, which has an Indonesian population of $57.5 \%$, and in the Sumatera Island, which has an Indonesian population of $21.3 \%$. Both islands, which are the largest and most populated islands in Indonesia, have an Indonesian population of 78.8\%. Three hundred and two salesmen working under 49 sales supervisors controlling the sales office or stock point depot participated in this study. Questionnaires were delivered to sales supervisors. The sales supervisors will evaluate the process performance and output performance of each salesman in the 
sales area and put a score into the questionnaire's items. The items in the questionnaire about positive selling ambience were scored by each salesman individually. Finally, data from 268 salesmen were analysed. After the data normalization processing step, only 229 data units are used to finalize the process of testing the hypotheses.

This study investigates input performance (salespeople's innovativeness and value-based selling capability), process performance (sales team tacit knowledge exchange and positive selling ambience) and output performance (sales performance) in the setting of sales process management. The primary consideration in choosing the respondents is based on the methodological study of Mount et al. (1994), who demonstrated both that the validity of personality constructs may be understated through reliance on the self-report method alone and that observer ratings (such as supervisor, co-worker or customer) are valid predictors of performance ratings for job-relevant dimensions. This is the reason for choosing sales supervisors to rate the input performance, process performance and output performance of salespeople under their supervision.

\section{Measures and testing of validity and reliability}

Measures used in this study were adapted from existing studies. Salespeople innovativeness measures are based upon Chen et al. (2015), who asked the supervisor to rate salesmen's performance activity on a scale from 0 to 10 . This measure consists of creative selling ability, creativity in new types of selling ability, the ability to solve problems in different ways, and an innovative selling process ability. Value-based selling capability is adapted from Ruiz et al. (2008) and Töytäri and Rajala (2015). This measure is composed of the ability to offer good service for price, the ability to articulate worth in time, effort, money, and the ability to make customers feel that they are getting their money's worth.

Measures of a sales team's tacit knowledge exchange is based on the concept of Eng (2006) (as adapted by Arnett and Wittmann (2014)), who has developed measures of teaching each other learned knowledge and successful or unsuccessful experience sharing. Moreover, measures of positive selling ambience are adapted from Chakrabarty et al. (2014). This variable is measured by asking supervisors to use their experience to provide a rating from 0 to 10 when accompanying salesman to sales calls and sales conversations based on the influential atmosphere in sales conversations, positive-twist conversations, and the ability to create a comfortable feeling in sales conversations. Sales performance is measured using common indicators such as sales volume in terms of number of units sold (Mariadoss et al., 2014, Guenzi et al., 2014, Flaherty and Pappas, 2012), sales value in terms of the monetary value created by the number of units sold (Mariadoss et al., 2014, Flaherty and Pappas, 2012), and sales growth (Chakrabarty et al., 2014, Spillecke and Brettel, 2013). The sales supervisor was asked to rate sales volume, sales value, and sales growth from 0 to 10 to compensate for reluctance to answer in terms of absolute measures such as the number of units sold, the monetary value of units sold and real percentage of sales growth. The final data from 49 sales supervisors overseeing 229 salespersons were then analysed using confirmatory factor analysis of structural equation modelling software SEM AMOS 23. The descriptive statistics on scale and 
measurement estimates, construct reliability, and convergent validity are presented in Table 1.

Table 1. Scale and measurement estimates, construct reliability and convergent validity

\begin{tabular}{|c|c|c|c|c|}
\hline VARIABLE \& INDICATOR & SOURCE & $\begin{array}{l}\text { STD. } \\
\text { LOADING }\end{array}$ & $\begin{array}{l}\text { CONSTRUCT } \\
\text { RELIABILITY }\end{array}$ & $\begin{array}{l}\text { CONVERGENT } \\
\text { VALIDITY }\end{array}$ \\
\hline Sales people & Adapted from & & 0.923 & 0.752 \\
\hline innovativeness & Chen et al. (2015) & & & \\
\hline Creative selling ability & & 0.799 & & \\
\hline $\begin{array}{l}\text { Creative in new ways of } \\
\text { selling ability } \\
\text { Ability to solve problem }\end{array}$ & & 0.814 & & \\
\hline in different way & & 0.944 & & \\
\hline $\begin{array}{l}\text { Innovative selling } \\
\text { process ability }\end{array}$ & & 0.903 & & \\
\hline Value-based selling & Adapted from & & 0.895 & 0.740 \\
\hline capability & Töytäri \& Rajala & & & \\
\hline $\begin{array}{l}\text { Ability to offer good } \\
\text { service for price } \\
\text { Ability to articulate }\end{array}$ & $\begin{array}{l}\text { (2015) and Ruiz, } \\
\text { Gremler, Wasburn, } \\
\text { \& Carrión }(2008)\end{array}$ & 0.812 & & \\
\hline $\begin{array}{l}\text { worth in time, effort } \\
\text { and money }\end{array}$ & & 0876 & & \\
\hline $\begin{array}{l}\text { Ability to make } \\
\text { customer's felling of } \\
\text { getting his/her money's } \\
\text { worth }\end{array}$ & & 0.89 & & \\
\hline Sales team tacit & Adapted from Eng & & 0.912 & 0.776 \\
\hline knowledge exchange & (2006) and Arnett & & & \\
\hline $\begin{array}{l}\text { Teaching each other the } \\
\text { learned knowledge }\end{array}$ & $\begin{array}{l}\text { \& Wittmann, } \\
(2014)\end{array}$ & 0.844 & & \\
\hline Voluntarily pass on the & & & & \\
\hline learned knowledge & & 0.902 & & \\
\hline $\begin{array}{l}\text { Sharing of unsuccessful } \\
\text { experience }\end{array}$ & & 0.895 & & \\
\hline Positive selling ambience & Adapted from & & 0.901 & 0.753 \\
\hline $\begin{array}{l}\text { Influential atmosphere } \\
\text { in sales conversation }\end{array}$ & $\begin{array}{l}\text { Chakrabarty et al. } \\
\text { (2014) }\end{array}$ & 0.955 & & \\
\hline $\begin{array}{l}\text { Positive twist } \\
\text { conversation }\end{array}$ & & 0.835 & & \\
\hline $\begin{array}{l}\text { Comfortable feeling in } \\
\text { sales conversation }\end{array}$ & & 0.807 & & \\
\hline Sales performance & Adapted from & & 0.912 & 0.775 \\
\hline Sales volume & Chakrabarty et al., & 0.865 & & \\
\hline Sales value & 2014; Spillecke \& & 0.879 & & \\
\hline Sales growth & $\begin{array}{l}\text { Brettel, 2013). } \\
\text { Flaherty \& Pappas, } \\
\text { 2012; Guenzi et al., } \\
\text { 2014; Mariadoss et } \\
\text { al., } 2014\end{array}$ & 0.897 & & \\
\hline
\end{tabular}

Source: Authors' own data processing.

The confirmatory factor analysis resulted in the loading factor for every construct or variable in the model being above the minimum expected value of 0.50 , with a critical ratio being larger than 1.96 (Arbuckle, 2016), thus indicating that the 
magnitude of each indicator's contribution to the constructed variables is accepted with a significance level lower than 0.05 at the critical ratio $\geq 1.96$; therefore, these indicators are accepted for further analysis. All the construct variables have an excellent construct reliability, such as salespeople innovativeness (0.923), valuebased selling capability (0.895), sales team's tacit knowledge exchange (0.912), positive selling ambience (0.901) and sales performance (0.912). Construct validity is measured by AVE (average variance extracted), with a minimum level of $\geq 0.50$. The analysis resulted in a level of accepted convergence validity, such as 0.752 for salespeople's innovativeness, 0.740 for value-based selling capability, 0.776 for sales team's tacit knowledge exchange, 0.754 for positive selling ambience, and 0.788 for sales performance. The calculation of the mean and the correlations across constructs are presented in Table 2.

Table 2. Mean, Correlation across constructs, Construct's reliability*)

\begin{tabular}{|c|c|c|c|c|c|c|c|c|c|}
\hline \multirow{3}{*}{$\begin{array}{l}\text { Variable } \\
\text { Value Based } \\
\text { Selling } \\
\text { Capability }\end{array}$} & \multirow{2}{*}{$\begin{array}{l}\text { CODE } \\
\text { VBSC }\end{array}$} & \multirow{2}{*}{$\begin{array}{l}\text { Mean } \\
7.37\end{array}$} & \multicolumn{2}{|c|}{ Std. Dev.Correlation } & VBSC & SP & KE & SI & SA \\
\hline & & & 1.33 & Pearson Correlation. & $\left.895^{*}\right)$ & & & & \\
\hline & & & & Implied Correlation & & & & & \\
\hline & & & & Sig. (2-tailed) & & & & & \\
\hline \multirow{3}{*}{$\begin{array}{l}\text { Sales } \\
\text { Performance }\end{array}$} & SP & 7.76 & 1.12 & Pearson Correlation & $.525^{* *}$ & 912*) & & & \\
\hline & & & & Implied Correlation & 169 & & & & \\
\hline & & & & Sig. (2-tailed) & 0.00 & & & & \\
\hline \multirow{3}{*}{$\begin{array}{l}\text { Sales Team } \\
\text { Knowledge } \\
\text { Exchange }\end{array}$} & KE & 7.69 & 1.27 & Pearson Correlation & $.383^{* *}$ & $.370^{* *}$. & $\left.912^{*}\right)$ & & \\
\hline & & & & Implied Correlation & .031 & .253 & & & \\
\hline & & & & Sig. (2-tailed) & 0.00 & 0.00 & & & \\
\hline \multirow{3}{*}{$\begin{array}{l}\text { Salespeople } \\
\text { Innovativeness }\end{array}$} & SI & 7.71 & 1.12 & Pearson Correlation & $.383^{* *}$ & $.228^{* *}$ & $218^{* *}$ & $23 *$ & \\
\hline & & & & Implied Correlation & 169 & .247 & .243 & & \\
\hline & & & & Sig. (2-tailed) & 0.00 & 0.001 & 0.001 & & \\
\hline \multirow{3}{*}{$\begin{array}{l}\text { Positive Selling } \\
\text { Ambience } \\
\text { Initiative }\end{array}$} & SA & 7.49 & 1.17 & Pearson Correlation & $.147^{*}$ & $.207^{* *}$ & .123 & .11. & $\left.3^{*}\right)$ \\
\hline & & & & Implied Correlation & .051 & .584 & .431 & .398 & \\
\hline & & & & Sig. (2-tailed) & .027 & .002 & .064 & .097 & \\
\hline
\end{tabular}

Source: Authors' own data processing.

The variable with the highest mean score is sales performance (7.76), followed by salespeople innovativeness (7.71), sales team tacit knowledge exchange (7.69) and positive selling ambiance initiative (7.49). The variable with the lowest score is the value-based selling capability (7.37). Correlations (measured by Pearson correlation 
complemented with the implied correlation produced by SEM AMOS) between indicators of the hypothesized variables are significant, as expected, such as the correlations between TK and SI (significant at 0.001), KE and VBSC (significant at 0.00 ), SI and VBSC (significant at 0.00), SI and SA (significant at 9.7\%), SA and SP (significant at 0.002) and VBSC and SP (significant at 0.00)

\section{Hypotheses testing}

To test the acceptance of the proposed model and the hypotheses, as developed in the previous section, a full SEM analysis was performed. In the proposed empirical research model, sales team tacit knowledge exchange is considered as exogenous variable, while salespeople innovativeness, positive selling ambience initiative, valuebased selling capability and sales performance are considered as endogenous variables. The result of the full SEM analysis is presented in Figure 1.

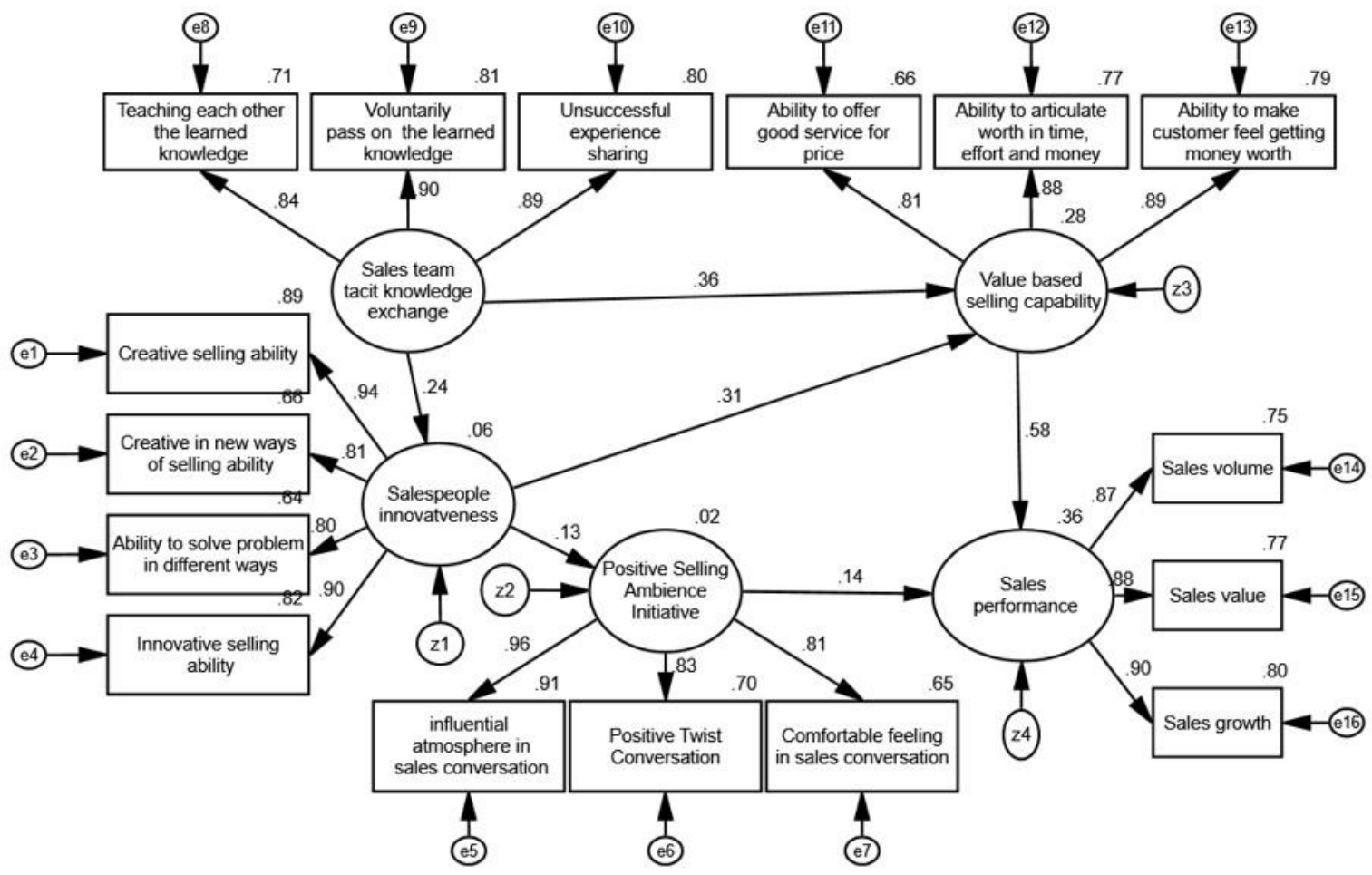

Figure 1. Full Structural Model Analysis

Source: Authors' own data processing.

Based on the SEM inferential statistical measures, a summary of the hypotheses testing result is presented in Table 3. 
Table 3. Hypotheses Testing Indicator

\begin{tabular}{|c|c|c|c|c|c|c|}
\hline The hypothesized relationship & $\begin{array}{r}\text { Std. } \\
\text { Estimate } \\
\end{array}$ & Estimate & S.E. & C.R. & $\mathrm{P}$ & Conclusion \\
\hline $\begin{array}{l}\text { Tacit knowledge exchange } \rightarrow \text { Salespeople } \\
\text { innovativeness }\end{array}$ & .242 & .189 & .056 & 3.395 & $* * *$ & Supported \\
\hline $\begin{array}{l}\text { Salespeople innovativeness } \rightarrow \text { Value-based } \\
\text { selling capability }\end{array}$ & .312 & .446 & .098 & 4.565 & $* * *$ & Supported \\
\hline $\begin{array}{l}\text { Salespeople innovativeness } \rightarrow \text { Positive } \\
\text { selling ambience }\end{array}$ & .128 & .162 & .089 & 1.814 & $.07^{*}$ & Supported \\
\hline $\begin{array}{l}\text { Tacit knowledge exchange } \rightarrow \text { Value-based } \\
\text { selling capability }\end{array}$ & .356 & .397 & .077 & 5.123 & $* * *$ & Supported \\
\hline $\begin{array}{l}\text { Value-based selling capability } \rightarrow \text { Sales } \\
\text { performance }\end{array}$ & .577 & .503 & .061 & 8.228 & $* * *$ & Supported \\
\hline $\begin{array}{l}\text { Positive selling ambience } \rightarrow \text { Sales } \\
\text { performance }\end{array}$ & .140 & .138 & .06 & \multicolumn{2}{|c|}{$2.302 .021^{* *}$} & Supported \\
\hline Goodness of fit & & & & & & Result \\
\hline Chi-square & & & & & & 164.536 \\
\hline Significance & & & & & & .000 \\
\hline Goodness of fit index & & & & & & .919 \\
\hline Comparative fit index & & & & & & .976 \\
\hline Tucker Lewis index & & & & & & .970 \\
\hline $\begin{array}{l}\text { RMSEA } \\
\text { ***) Significant } \leq 1 \% \\
{ }^{* *)} \text { Significant } \leq 5 \% \\
\quad{ }^{*)} \text { Significant } \leq 10 \%\end{array}$ & & & & & & .055 \\
\hline
\end{tabular}

Source: Authors' own data processing.

As shown in Table 3, our proposed model is well supported, with good GFI (0.919), good CFI (0.976), good TLI (0.970) and good RMSEA (0.055). As the critical ratio for $\mathrm{H} 1, \mathrm{H} 2, \mathrm{H} 4, \mathrm{H} 5, \mathrm{H} 6$ is greater than the cut-off value of 1.96 , with the significance probability lower than $5 \%$, the conclusion is that the five hypotheses are well accepted or supported by the data. Hypothesis 3 is still accepted with the level of significance probability of lower than $10 \%$. The acceptance level of $10 \%$ is still acceptable in marketing research such as this has appeared in several studies (Menon et al., 1999).

\section{Findings and discussion}

Considering the importance of the variables in the model, the accepted model in this study returned important findings related to several strategic pathways for enhancing sales performance. The first strategic path is that sales team tacit knowledge exchange is a process for enhancing a salesforce's personal capabilities, especially in translating the unarticulated knowledge and experience of team members in cultivating the specific capabilities of peer members in the sales team. A better process of tacit knowledge exchange could be a strategic tool for enhancing the transactional value transferred to the customer. The better the capability of transferring value to the 
customer, the higher the sales performance would be. This finding agrees and develops the previous studies (Tsai and Li, 2007, Teece, 1998, Fu et al., 2011, Spanjol et al., 2011, Arnett and Wittmann, 2014), pointing out that sales team tacit knowledge enables firms to apply important knowledge in operational activities, resulting in both value creation and better performance. As suggested in the article of Subanidja and Hadiwidjojo (2017), the current study contributes in the detailing of process how organizational learning and knowledge management leverages the spreading effect of tacit knowledge gained from the past experiences in enhancing organizational capabilities particularly enhancing the innovativeness of sales human capital as a strategic asset in enabling value based selling capability. If this process could be appropriately managed, it will provide ways for enhancing sales growth performance.

The second pathway is that lending the core ingredient of organizational learning such as testing and transforming experience into workable knowledge and skill and sharing knowledge that is either explicit or tacit to the organization member (Škerlavaj et al., 2010) will empower sales teamwork, leading to innovativeness. This study's findings have demonstrated the importance of sales team tacit knowledge exchange in cultivating knowledge, which is a key to improving salespeople's innovativeness. These findings extend Chen et al.'s (2015) finding that salespeople's innovativeness is a type of strategic input with the potential to empower the ability to articulate value for the customer and that the ability to articulate the value proposition is a prerequisite for new product sales performance. The current study's finding strengthens the argument that in tacit knowledge exchange process, member of sales peer group will knowing who knows what, where expertise is and what expertise is required (Spraggon and Bodolica, 2017), and what expertise is transplanted for enhancing a collective members' cognition and produce novel ideas for tackling work-related concerns especially in the very competitive and dynamic situation of selling activity.

This study is in line with Škerlavaj et al. (2010) finding that tacit knowledge exchange is an antecedent to improve innovativeness in the sense that sales people are becoming more creative and innovative, which can be developed and supported by an organizational environment such as team building, knowledge sharing, tacit knowledge sharing, and a supervisory system. The more innovative the sales people, the better the ability to transfer value to the customer as a strategic tool for improving sales performance, which is supported by previous studies (Ruiz et al., 2008, Kim et al., 2010, Lilford et al., 2014) suggesting that delivering the best customer value is a key to enhancing performance.

The final pathway is that tacit knowledge exchange between sales team members will enhance salespeople's innovativeness. This innovativeness is a tool for increasing salespeople's initiative to create a positive selling ambience. A positive selling ambience is believed to contribute to increased sales performance. Moreover, learning, which consists of learning from failure, learning from others' success stories, and exchanging experiences, is a common practice of salespeople who are brought up in a teamwork-oriented professional environment such as working under the same supervisor or serving the same sales area. In this situation, tacit knowledge exchange may occur. The acceptance of the hypothesis on the relationship between sales team tacit knowledge exchange and salespeople's innovativeness demonstrated the 
importance of good practices in salesforce development programmes such as teaching each other past learned knowledge, especially unarticulated knowledge obtained from past work experience, voluntarily passing on learned knowledge to sales peers, and sharing unsuccessful experiences to discuss possible solutions. Exchanging tacit knowledge is believed to be one of the strategic tools for empowering salespeople's innovativeness. Supporting Alwis and Hartmann (2008), this study has examined the role of tacit knowledge exchange in enhancing salesforce innovativeness such as enhancing the ability to sell creatively, the ability to develop creative ways of handling selling issues, the ability to creatively solve problems in several ways, and in summary, enhancing the ability to sell innovatively.

Based on the acceptance of the hypothesis on the relationship between sales team tacit knowledge exchange and value-added selling capability and the relationship between value-added sales capability and sales performance, this study suggests that empowering salespeople through efforts to transform tacit knowledge into specific skills through exchanging not only unarticulated knowledge and experience, but also successful and unsuccessful experiences in selling processes, to a team member will empower salespeople's selling capability such as the ability to create an influential atmosphere in a sales conversation, the ability to energize sales processes with a positive-twist conversation, and the ability to manage a comfortable feeling in a sales conversation. This finding provides an actual evidence to the previous studies as appeared in Spraggon and Bodolica (2017) that a tacit knowledge exchange will produced a portfolio of novel ideas in the group member that potential for enhancing the innovativeness in tackling the work-related concerns done by salespeople. If this situation occurs, better sales performance can be achieved.

This study found that salespeople's innovativeness will improve the positive selling ambience initiative, which in turn enhances sales performance. This is the answer to this study's main question about how salespeople innovativeness leverages sales performance. An innovative salesperson with creative selling ability, creativity in his/her ability to provide new ways of selling, several different approaches or methods of problem solving or the ability to sell innovatively will enhance his/her imitativeness in maintaining a positive selling ambience. An innovative salesperson will enhance the positive selling ambience, for example, by ensuring that service for price is achieved, positively articulating worth in terms of the customer's time, value and money and causing the customer to have a good feeling about getting his/her money's worth. The positive selling ambience initiative will have a sizable impact on improving sales conversation success, as measured by increased sales volume, sales value and sales growth.

\section{Limitation and future research}

This study was completed with a well-prepared process, but still comes with several limitations. The first limitation is due to the sample scope is only a marketing company that serving all part of the country, the generalizability of the study is limited but could be transplanted to the other companies and industries salesforce. Therefore, a research venue is open for testing the model in other industries selling products as well as selling services. The second limitation is the current study only focus to the consumer product salespeople, its application to industrial product salespeople might 
be not relevant. Therefore, a call for study should go to integrate the model for both type of salespeople, consumer product salespeople as well as industrial product/service salespeople.

This study has developed and investigated a comprehensive framework by integrating tacit knowledge, salespeople's innovativeness, customer value, positive selling ambience, and sales performance. Simultaneously, this study suggests several areas that call for further research. First, there is a need to replicate the extended model in the business-to-business marketing context or other fast-moving consumer goods (FMCG). In addition, further research might explore the influence of salespeople's satisfaction and leadership quality placed in the model.

This study has investigated the positive impact of salespeople's innovation on sales performance using a cross-sectional design survey. There should be a time interval between increasing salespeople's innovation and improving sales performance. Therefore, this investigation suggests longitudinal research.

\section{References}

Ali, I. (2018), "Personality traits, individual innovativeness and satisfaction with life", Journal of Innovation \& Knowledge. Available at: https://doi.org/10.1016/j.jik.2017.11.002.

Alwis, R.-S.-D. and Hartmann, E. (2008), "The use of tacit knowledge within innovative companies: knowledge management in innovative enterprises", Journal of Knowledge Management, Vol. 12, No. 1, pp. 133-147.

Arbuckle, J. L. (2016), IBM® SPSS $®$ Amos $^{\mathrm{TM}}$ User's Guide.

Arnett, D. B. and Wittmann, C. M. (2014), "Improving marketing success: The role of tacit knowledge exchange between sales and marketing", Journal of Business Research, Vol. 67, No. 3, pp. 324-331.

Bennet, D. and Bennet, A. (2008), "Engaging tacit knowledge in support of organizational learning", VINE, Vol. 38, No. 1, pp. 72-94.

Bologa, R. and Lupu, A. R. (2014), "Organizational learning networks that can increase the productivity of IT consulting companies. A case study for ERP consultants", Expert Systems with Applications, Vol. 41, No. 1, pp. 126-136.

Bontis, N., Crossan, M. M. and Hulland, J. (2002), "Managing an organizational learning system by aligning stocks and flows", Journal of Management Studies, Vol. 39, No. 4, pp. 437-469.

Burke, L. A. and Witt, L. A. (2002), "Moderators of the openness to experience-performance relationship", Journal of Managerial Psychology, Vol. 17, No. 8, pp. 712-721.

Cangemi, J. and Miller, R. (2007), "Breaking-out-of-the-box in organizations: Structuring a positive climate for the development of creativity in the workplace", Journal of Management Development, Vol. 26, No. 5, pp. 401-410.

Cavusgil, S. T., Roger, J. C. and Yushan, Z. (2003), "Tacit knowledge transfer and firm innovation capability", Journal of Business \& Industrial Marketing, Vol. 18, No. 1, pp. 6-21.

Chakrabarty, S., Widing, R. E. and Brown, G. (2014), "Selling behaviours and sales performance: the moderating and mediating effects of interpersonal 
mentalizing", Journal of Personal Selling \& Sales Management, Vol. 34, No. 2, pp. 112-122.

Chen, A., Peng, N. and Hung, K.-P. (2015), "Managing salespeople strategically when promoting new products-Incorporating market orientation into a sales management control framework", Industrial Marketing Management, 51, pp. 141-149.

Chen, L. and Mohamed, S. (2010), "The strategic importance of tacit knowledge management activities in construction", Construction Innovation, Vol. 10, No. 2, pp. 138-163.

Choi, Y., Huang, Y. and Sternquist, B. (2015), "The effects of the salesperson's characteristics on buyer-seller relationships", The Journal of Business \& Industrial Marketing, Vol. 30, No. 5, pp. 616-625.

Eng, T.-Y. (2006), "An investigation into the mediating role of cross-functional coordination on the linkage between organizational norms and SCM performance", Industrial Marketing Management, Vol. 35, No. 6, pp. 762-773.

Fiore, A. M., Niehm, L. S., Hurst, J. L., Son, J. and Sadachar, A. (2017), "Entrepreneurial Marketing: Scale Validation with Small, Independently-Owned Businesses", Journal of Marketing Development and Competitiveness, Vol. 7, No. 4, pp. 6386.

Flaherty, K. E. and Pappas, J. M. (2012), "Control mechanisms, idea transfer, and performance in sales organizations", Industrial Marketing Management, Vol. 41, No. 5, pp. 841-848.

Foos, T., Schum, G. and Rothenberg, S. (2006), "Tacit knowledge transfer and the knowledge disconnect", Journal of Knowledge Management, Vol. 10, No. 1, pp. 6-18.

Fu, X., Dresner, M. and Oum, T. H. (2011), "Effects of transport service differentiation in the US domestic airline market", Transportation Research Part E: Logistics and Transportation Review, Vol. 47, No. 3, pp. 297-305.

García-Morales, V. J., Jiménez-Barrionuevo, M. M. and Gutiérrez-Gutiérrez, L. (2012), "Transformational leadership influence on organizational performance through organizational learning and innovation", Journal of Business Research, Vol. 65, No. 7, pp. 1040-1050.

Glińska-Neweś, A., Sudolska, A., Karwacki, A. and Górka, J. (2017), " Innovations among people. How positive relationships at work can trigger innovation creation ", E+M Ekonomie a Management, Vol. 20, No. 3, pp. 84-100.

Guenzi, P., Baldauf, A. and Panagopoulos, N. G. (2014), "The influence of formal and informal sales controls on customer-directed selling behaviors and sales unit effectiveness", Industrial Marketing Management, Vol. 43, No. 5, pp. 786-800.

Hallbäck, J. and Gabrielsson, P. (2013), "Entrepreneurial marketing strategies during the growth of international new ventures originating in small and open economies", International Business Review, Vol. 22, No. 6, pp. 1008-1020.

Heap, N. (1996), "Building the organizational team", Industrial and Commercial Training, Vol. 28, No. 3, pp. 3-7.

Holste, J. S. and Dail, F. (2010), "Trust and tacit knowledge sharing and use", Journal of Knowledge Management, Vol. 14, No. 1, pp. 128-140. 
$\mathrm{Hu}, \mathrm{B}$. (2014), "Linking business models with technological innovation performance through organizational learning", European Management Journal, Vol. 32, No. 4, 587-595.

Ionitã, D. (2012), "Entrepreneurial Marketing: A New Approach For Challenging Times", Management \& Marketing, Vol. 7, No. 1, pp. 131-150.

Jiménez-Jiménez, D. and Sanz-Valle, R. (2011), "Innovation, organizational learning, and performance", Journal of Business Research, Vol. 64, No. 4, pp. 408-417.

Kim, J. E. and Kim, J. (2012), "Human factors in retail environments: a review", International Journal of Retail \& Distribution Management, Vol. 40, No. 11, pp. 818-841.

Kim, M., Kim, S. and Lee, Y. (2010), "The effect of distribution channel diversification of foreign luxury fashion brands on consumers' brand value and loyalty in the Korean market", Journal of Retailing and Consumer Services, Vol. 17, No. 4, pp. 286-293.

Kuo-Pin, Y., Hsin-Hua, H. and Yu-Jen, C. (2015), "The comfort zone of the value circumplex for entrepreneurship: a structural analysis", Career Development International, Vol. 20, No. 6, pp. 663-683.

Lacroix, C., Lussier, B. and Ouellet, J.-F. (2014), "Concern with the Well-Being of Future Generations Makes Salespeople More Innovative - But Does It Make Them More Performant?", Journal of Marketing Development and Competitiveness, Vol. 8, No. 3, 49-58.

Lee, W. I., Wu Chen, C., Hao Chen, T. and Yuan Chen, C. (2010), "The relationship between consumer orientation, service value, medical care service quality and patient satisfaction: The case of a medical center in Southern Taiwan", African Journal of Business Management, Vol. 4, No., 4, pp. 448-458.

Lilford, N., Vigar-Ellis, D. and Nel, D. (2014), "Big Five personality traits and financial salesperson performance: An application of Chernoff faces", Journal of Financial Services Marketing, Vol. 19, No. 2, pp. 146-154.

López Sánchez, J. Á., Santos Vijande, M. L. and Trespalacios Gutiérrez, J. A. (2011), "The effects of manufacturer's organizational learning on distributor satisfaction and loyalty in industrial markets", Industrial Marketing Management, Vol. 40, No. 4, pp. 624-635.

Malik, A., Sinha, A. and Blumenfeld, S. (2012), "Role of quality management capabilities in developing market-based organisational learning capabilities: Case study evidence from four Indian business process outsourcing firms", Industrial Marketing Management, Vol. 41, No. 4, pp. 639-648.

Mariadoss, B. J., Milewicz, C., Lee, S. and Sahaym, A. (2014), "Salesperson competitive intelligence and performance: The role of product knowledge and sales force automation usage", Industrial Marketing Management, Vol. 43, No. 1, pp. 136145.

Matošková, J. and Směšná, P. (2017), "Human resource management practices stimulating knowledge sharing", Management \& Marketing, Vol. 12, No. 4, pp. 614-632.

Menon, A., Bharadwaj, S. G., Phani Tej, A. and Edison, S. W. (1999), "Antecedents and consequences of marketing strategy making: A model and a test", Journal of Marketing, 63, pp. 18-40. 
Mie, A. and Morten Thanning, V. (1999), "Networks, cognition and management of tacit knowledge", Journal of Knowledge Management, Vol. 3, No. 4, pp. 252-261.

Morris, M. H., Schindehutte, M. and Laforge, R. W. (2002), "Entrepreneurial marketing: A construct for integrating emerging entrepreneurship and marketing perspectives", Journal of Marketing Theory and Practice, Vol. 10, No. 4, pp. 119.

Mount, M. K., Barrick, M. R. and Strauss, J. P. (1994), "Validity of Observer Ratings of the Big Five Personality Factors", Journal of Applied Psychology, Vol. 79, No. 2, pp. 272-280.

Paparoidamis, N. G. (2005), "Learning orientation and leadership quality: Their impact on salespersons' performance", Management Decision, Vol. 43, No. 7/8, pp. 1054-1063.

Rahman, M. S., Osman-Gani, A. M., Momen, M. A. and Islam, N. (2015), "Testing knowledge sharing effectiveness: trust, motivation, leadership style, workplace spirituality and social network embedded model", Management \& Marketing, Vol. 10, No. 4, pp. 284-303.

Ruiz, D. M., Gremler, D. D., Wasburn, J. H. and Carrión, G. C. (2008), "Service value revisited: Specifying a higher-order, formative measure", Journal of Business Research, Vol. 61, No. 12, pp. 1278-1291.

Santos-Vijande, M. L., López-Sánchez, J. Á. and Trespalacios, J. A. (2012), "How organizational learning affects a firm's flexibility, competitive strategy, and performance", Journal of Business Research, Vol. 65, No. 8, pp. 1079-1089.

Shahzadi, M., Malik, S. A., Ahmad, M. and Shabbir, A. (2018), "Perceptions of fine dining restaurants in Pakistan: What influences customer satisfaction and behavioral intentions?", International Journal of Quality \& Reliability Management, Vol. 35, No. 3, pp. 635-655.

Sheng, M. L. and Chien, I. (2016), "Rethinking organizational learning orientation on radical and incremental innovation in high-tech firms", Journal of Business Research, Vol. 69, No. 6, pp. 2302-2308.

Sigala, M. and Chalkiti, K. (2007), "Improving performance through tacit knowledge externalisation and utilisation: Preliminary findings from Greek hotels", International Journal of Productivity and Performance Management, Vol. 56, No. 5/6, pp. 456-483.

Škerlavaj, M., Song, J. H. and Lee, Y. (2010): "Organizational learning culture, innovative culture and innovations in South Korean firms", Expert Systems with Applications, Vol. 37, No. 9, pp. 6390-6403.

Smith, D. A. and Lohrke, F. T. (2008), "Entrepreneurial network development: Trusting in the process", Journal of Business Research, Vol. 61, No. 4, pp. 315-322.

Spanjol, J., Tam, L., Qualls, W. J. and Bohlmann, J. D. (2011), "New Product Team Decision Making: Regulatory Focus Effects on Number, Type, and Timing Decisions", The Journal of Product Innovation Management, Vol. 28, No. 5, pp. 623-640.

Spillecke, S. B. and Brettel, M. (2013), "The impact of sales management controls on the entrepreneurial orientation of the sales department", European Management Journal, Vol. 31, No. 4, pp. 410-422. 
Spraggon, M. and Bodolica, V. (2017), "Collective tacit knowledge generation through play", Management Decision, Vol. 55, No. 1, pp. 119-135.

Stuart, B. (2016), "Organizational learning? Look again", The Learning Organization, Vol. 23, No. 5, pp. 332-341.

Subanidja, S. and Hadiwidjojo, D. (2017), "The influence of knowledge management "bottleneck" on company's performance", Management \& Marketing, Vol. 12, No. 3, pp. 402-415.

Teece, D. J. (1998), "Capturing Value from Knowledge Assets: The new economy, market s for know-how, and intangible assets", California Management Review, Vol. 40, No. 3, pp. 55-79.

Tjosvold, D., Morishima, M. and Belsheim, J. A. (1999), "Complaint handling on the shop floor: Cooperative relationships and open-minded strategies", International Journal of Conflict Management, Vol. 10, No. 1, pp. 45-68.

Töytäri, P., Alejandro, T. B., Parvinen, P., Ollila, I. \& Rosendahl, N. (2011), "Bridging the theory to application gap in value-based selling", Journal of Business \& Industrial Marketing, Vol. 26, No. 7, pp. 493-502.

Töytäri, P. and Rajala, R. (2015), "Value-based selling: An organizational capability perspective", Industrial Marketing Management, 45, pp. 101-112.

Trond, H. \& Kjell, T. (2010), "Value-creation initiatives in buyer-seller relationships", European Business Review, Vol. 22, No. 5, pp. 539-555.

Tsai, M.-T. and Li, Y.-H. (2007), "Knowledge creation process in new venture strategy and performance", Journal of Business Research, Vol. 60, No. 4, pp. 371-381.

Yen-Chun, C., Adriana Amaya, R. and Wann-Yih, W. (2017), "Exploring the determinants and consequences of salesperson market orientation behavior: An empirical study in the financial service industry", Journal of Service Theory and Practice, Vol. 28, No. 2, pp. 170-195.

Yu, Y., Dong, X.-Y., Shen, K. N., Khalifa, M. and Hao, J.-X. (2013), "Strategies, technologies, and organizational learning for developing organizational innovativeness in emerging economies", Journal of Business Research, Vol. 66, No. 12, pp. 2507-2514.

Zaim, H., Gürcan, Ö. F., Tarım, M., Zaim, S. and Alpkan, L. (2015), "Determining the Critical Factors of Tacit Knowledge in Service Industry in Turkey", Procedia Social and Behavioral Sciences, 207, pp. 759-767. 